УДК 676.255.332

\author{
С.В. ПУТІНЦЕВА, Л.А. ЧУРСІНА, А.О. ТІХОСОВА
}

Херсонський національний технічний університет

\title{
ПОРІВНЯЛЬНА ХАРАКТЕРИСТИКА ПАПЕРУ, ОТРИМАНОГО 3 ЛЬОНУ ТА КОНОПЕЛЬ
}

\author{
S. PUTINTSEVA, L. CHURSINA, A. TICHOSOVA \\ Kherson National Technical University
}

\section{COMPARATIVE CHARACTERISTICS OF PAPERS OBTAINED FROM FLAX AND HEMP}

\section{https://doi.org/10.36910/6775-2310-5283-2021-14-24}

Мета. Здійснити порівняльний аналіз паперу, отриманого на основі волокна льону олійного та ненаркотичних конопель.

Методика. Дослідження в роботі проводили за допомогою сучасних теоретичних та експериментальних методів: експериментальні дослідження властивостей паперу, одержаного з волокон льону та конопель виконували з використанням стандартних методик $і$ засобів вимірювання, а саме: масу $1 \mathrm{M}^{2}$ паперу визначали інструментальним методом за ДСТУ 2297-93 (ГОСТ 13199-94) «Напівфабрикати волокнисті, папір та картон. Метод визначення маси продукиї площею $1 \mathrm{M}^{2} » ;$ визначення повітропроникності згідно $з$ ДСТУ 2906-94 (ГОСТ 30114-95) (ISO 5636-1:1984) «Папір та картон. Визначення повітропроникності (середній діапазон). Загальні вимоги до методів»; визначення білості згідно з ДСТУ 2570-94 (ГОСТ 30113-94) «Папір та картон. Метод визначення білості»; визначення абсолютного опору продавлюванню згідно з ДСТУ ISO 2758:2007 «Папір. Визначення опору продавлюванню (ISO 2758:2001, IDT)»; результати експериментальних досліджень обробляли із застосуванням методів математичної статистики за допомогою прикладних програм «MathCAD-2000», «Maple 6,5», «Microsoft Office Excel 2016» ma «Microsoft Office Word 2016».

Результати. Проаналізовано показники якості паперу, отриманого із класичних композицій (відповідно з бавовняної та деревної целюлози) та з композицій на основі рослинної сировини (целюлоза з волокна льону олійного + деревна целюлоза; целюлоза 3 конопляного лубу + хвойна целюлоза); підтверджено можливість отримання високоякісної целюлози з ненаркотичних сортів конопель та льону олійного; проведено порівняльний аналіз отриманих видів паперу; надано рекомендації щзодо вдосконалення технологій переробки соломи льону олійного та ненаркотичних сортів конопель в целюлозу, які дозволять раціонально використовувати власні ресурси. 
Наукова новизна. Визначено вплив різних видів целюлоз, одержаних з волокон льону олійного та ненаркотичних конопель на фізико-механічні властивості одержаних сортів паперу. Здійснено порівняльний аналіз їх якості.

Практична значимість. На основі одержаних споживних характеристик паперу різних сортів можливо встановлювати їх функціональне призначення та застосування в різних галузях виробництва. Встановлені в роботі споживні характеристики паперу 3 луб'яних культур підтверджують доиільність заміни імпортованої сировини бавовни та дефіцичтної деревної сировини для одержання різних видів паперу.

Ключові слова: ненаркотична конопля, папір, целюлоза, волокно, льон олійний.

Постановка проблеми у загальному вигляді та ії зв'язок із важливими науковими чи практичними завданнями. Завдяки підвищенню екологічної свідомості та пошуку альтернатив у сільському господарстві як в Україні, так і за іiі межами, спостерігається великий інтерес до луб'яних волокон та їх використання в різних галузях промисловості. Американські та канадські вчені порівнюють цей інтерес 3 Інтернетом, наголошуючи, що сучасний стан розвитку поглибленої переробки льону та конопель можна порівняти 3 розвитком Інтернету 20 років тому [1].

Попит на целюлозу з довгого волокна в Свропі та США становить уже 6 мільйонів тонн на рік. Для задоволення цього попиту площа під посіви конопель повинна становити 1 млн. га. У США, як і в Європі, існують обмеження щодо вирубки лісів. Однорічні рослини 3 луб'яних культур $\epsilon$ альтернативною сировиною для виробництва целюлози та паперу, меблів, автомобільної і текстильної промисловості.

Для України целюлоза - це виключно імпортна складова. Відсутність власного виробництва товарної целюлози в Україні зумовлена багатьма факторами, зокрема відсутністю деревних ресурсів. 31 га луб'яних культур збирають целюлози в 8-10 разів більше, ніж дає найшвидше зростаюче дерево в нашій кліматичній зоні - тополя. Луб'яні культури повинні зайняти гідне місце в економіці країни з точки зору сировини для виробництва целюлози. Отже, враховуючи обсяг вирощування льону олійного, кількість соломи та вихід целюлози із соломи та зростаючий інтерес до вирощування технічних конопель, можна стверджувати, що луб'яні культури, а саме льон та коноплі - $\epsilon$ перспективною целюлозовмісною сировиною для виробництва паперу, композиційних матеріалів та ін.

Аналіз останніх досліджень, у яких започатковано вирішення проблеми. Серед волокнистих рослин для одержання целюлози найбільш 
істотне місце займає бавовна, потім джут, агава, льон, капок, сизаль, рамі і коноплі. У 2000 р. світове виробництво волокна цих рослин налічувало близько 25 млн. тон, в тому числі волокон льону та конопель близько 700 тис. тон. Коноплю вирощували в першу чергу в Китаї, також в Румунії, Південній Кореї, Іспанії та Росії. За останні роки простежується тенденція зменшення виробництва луб'яних волокон, але ж у 2009-2015 рр. виробництво волокна льону та конопель стабілізувалося і досягло близько 350-400 тисяч тон.

В Україні на початку XXI століття площа посівів льону та конопель становила близько 6 тисяч гектар. Після 2010 року, згідно з Загальнодержавною цільовою програмою розвитку целюлозно-паперової промисловості України та вітчизняного ринку картонно-паперової продукції на період до 2020 року, в якій передбачено використання однорічних рослин для створення вітчизняної сировинної бази паперової промисловості відбулося збільшення посівних площ луб'яних культур, а саме: льону i конопель та виробництва льоно- i коноплеволокна (табл. 1, 2).

Таблиця 1. Динаміка посівних площ льону та конопель в Україні

\begin{tabular}{|c|c|c|}
\hline Рік & Льон олійний, тис. га & Конопля технічна, тис. га \\
\hline 2000 & 2,2 & 3,0 \\
\hline 2010 & 56,3 & 0,8 \\
\hline 2015 & 62,1 & 3,0 \\
\hline 2016 & 68,4 & 0,2 \\
\hline 2017 & 47,1 & 2,8 \\
\hline 2018 & 31,5 & 1,1 \\
\hline 2019 & 16,1 & 1,0 \\
\hline 2020 & 13,5 & $\ldots$ \\
\hline
\end{tabular}

... - дані відсутні

Таблиця 2. Динаміка виробництва льоно- та коноплеволокна в Україні

\begin{tabular}{|c|c|c|}
\hline Рік & Льон олійний, тис. т & Конопля технічна, тис. т \\
\hline 2000 & 1,2 & $\ldots$ \\
\hline 2010 & 46,8 & $\ldots, 4$ \\
\hline 2015 & 68,6 & 2,7 \\
\hline 2016 & 91,8 & 2,2 \\
\hline 2017 & 45,6 & 0,8 \\
\hline 2018 & 23,6 & 0,2 \\
\hline 2019 & 15,2 & $\ldots$ \\
\hline 2020 & $\ldots$ & $\ldots$ \\
\hline
\end{tabular}

... - дані відсутні 
3 даних, наведених в таблицях 1, 2 простежується зниження показників починаючи з 2017 року. Основними причинами такої ситуації були складні фінансові та кредитні умови, які не враховували особливий характер цієї галузі та проблеми зі збутом на внутрішньому та зовнішньому ринках, що виникли в результаті імпорту з Європейського Союзу субсидованої продукції. Відсутність виробництва целюлози у паперовій промисловості, яка тісно пов'язана із сільським господарством, призвела до погіршення продажів сировини. До основних причин занепаду галузі можна також віднести посилення державою законодавчих вимог щодо вирощування конопель у зв'язку із вмістом у ній психоактивних речовин.

На даний момент зростає інтерес галузі до рослин, що відновлюють грунти, до яких належать льон та коноплі.

В останні роки вчені з Інституту луб'яних культур УААН створили сорти конопель, які не містять психоактивної речовини, що не представляє соціальної загрози для суспільства. Ці нові види конопель були випробувані в лабораторних та експериментальних умовах як сировина для виробництва целюлози. Також були розроблені інноваційні технології вирощування та збирання конопель [2].

Цілі статті полягають у розробці рекомендацій, спрямованих на розширення сфери використання волокон льону та конопель в целюлознопаперовій промисловості та створення власної сировинної бази в Україні.

Об'єкт дослідження. Споживні характеристики паперу, отриманого 3 волокон льону олійного та ненаркотичних конопель.

Методи дослідження. Завдання, поставлені в статті, вирішувалися за допомогою сучасних методів теоретичних і експериментальних досліджень:

- експериментальні дослідження властивостей паперу, одержаного 3 волокон льону та конопель виконували з використанням стандартних методик і засобів вимірювання, а саме: масу $1 \mathrm{~m}^{2}$ паперу визначали інструментальним методом за ДСТУ 2297-93 (ГОСТ 13199-94) «Напівфабрикати волокнисті, папір та картон. Метод визначення маси продукції площею $1 \mathrm{~m}^{2} »$ [3]; визначення повітропроникності згідно з ДСТУ 2906-94 (ГОСТ 30114-95) (ISO 5636-1:1984) «Папір та картон. Визначення повітропроникності (середній діапазон). Загальні вимоги до методів» [4]; визначення білості згідно з ДСТУ 2570-94 (ГОСТ 30113-94) «Папір та картон. Метод визначення білості»; визначення абсолютного опору продавлюванню згідно 3 ДСТУ ISO 2758:2007 «Папір. Визначення опору продавлюванню (ISO 2758:2001, IDT)»; 
- результати експериментальних досліджень обробляли із застосуванням методів математичної статистики за допомогою прикладних програм «MathCAD-2000», «Maple 6,5», «Microsoft Office Excel 2016» та «Microsoft Office Word 2016».

Виклад основного матеріалу дослідження 3 повним обгрунтуванням отриманих наукових результатів. Виробництво целюлози 3 волокна льону та конопель $є$ інноваційним та екологічним. Воно не містить таких речовин, як хлор і сірка, які характерні для традиційних технологій.

Дослідження та технологічні випробування показали, що вирощування конопель може забезпечити велику кількість біомаси (8-10 т / га). Конопляна солома містить близько 30 \% волокна, з якого виробляється довговолокниста целюлоза з виходом до 80 \%. Целюлоза з довгого волокна конопель може бути використана як сировина для виробництва спеціального високоякісного білого паперу (папір для банкнот, цінних паперів, надтонкий папір, папір для сигарет). Гемітермомеханічну целюлозу (ХТМЦ) із виходом 70 \%, папір 3 якої використовують для друку, упаковки тощо, можна отримати з соломи конопель без виділення костриці.

Під час виробництва целюлози 3 конопляної та лляної сировини для целюлозно-паперової промисловості необхідно враховувати іiі хімічний склад, анатомо-морфологічну структуру, фізико-механічні властивості

Характерною особливістю анатомічної будови льону та конопель $є$ наявність луб'яних волокнистих та деревних шарів. Перший шар становить 3040 \% від усього стебла, а другий - відповідно 60-70 \%. Луб'яний шар містить найцінніші целюлозні волокна, їх вміст становить 60-70 \%.

Хімічний склад луб'яної сировини, що потенційно розглядається як сировина для отримання целюлози, наведено в таблиці 3.

Таблиця 3. Хімічний склад та довжина волокон луб'яної сировини

\begin{tabular}{|l|c|c|c|c|}
\hline \multirow{2}{*}{$\begin{array}{c}\text { Хiмiчний склад та } \\
\text { довжина волокон }\end{array}$} & \multicolumn{4}{|c|}{ Стебло } \\
\cline { 2 - 5 } & \multicolumn{2}{|c|}{$\begin{array}{c}\text { волокниста частина або } \\
\text { луб }\end{array}$} & \multicolumn{2}{c|}{$\begin{array}{c}\text { деревна частина або } \\
\text { костриця }\end{array}$} \\
\cline { 2 - 5 } & льону & конопель & льону & конопель \\
\hline Целюлоза, \% & $63,4-76,4$ & $66,0-70,4$ & $46-52$ & $37,1-39,4$ \\
\hline Лігнін, \% & $2,9-4,9$ & $3,7-6,0$ & $24,8-26,3$ & $21,0-32,9$ \\
\hline Геміцелюлоза, \% & $8-12$ & $7,0-7,4$ & $14-16$ & $18,9-21,2$ \\
\hline Довжина волокон, мм & $9-70$ & $5,0-55,0$ & 1,0 & $0,60-0,75$ \\
\hline
\end{tabular}


Як видно 3 даних таблиці 3, хімічний склад волокна льону та конопель значно відрізняється від хімічного складу костриці. Луб'яні волокна містять 63,4-76,4 \% целюлози й до 6,0 \% лігніну, а костриця містить 46-52 \% целюлози та 21,0-32,9 \% лігніну.

Порівняльний аналіз розмірів волокон, що містяться в луб'яному шарі, та волокон, які розташовані в костриці, свідчить, що перші мають більшу довжину, i це зумовлює їх природну міцність. Довжина луб'яних волокон коливається в межах 5,0-70,0 мм, а довжина волокон, що знаходяться в костриці, становить 0,6-1,0 мм.

Таким чином, різниця в хімічному складі волокон та їх довжині вимагає розділення цих двох фракцій перед варінням целюлози, а також їх окремого використання для виробництва целюлози різного призначення [5].

Варіння целюлози проводили в кислотостійкому сталевому автоклаві місткістю 0,5 л у лабораторних умовах (рис. 1). Аналіз одержаного паперу проводили в лабораторіях ТОВ «Цюрупинська паперова компанія».

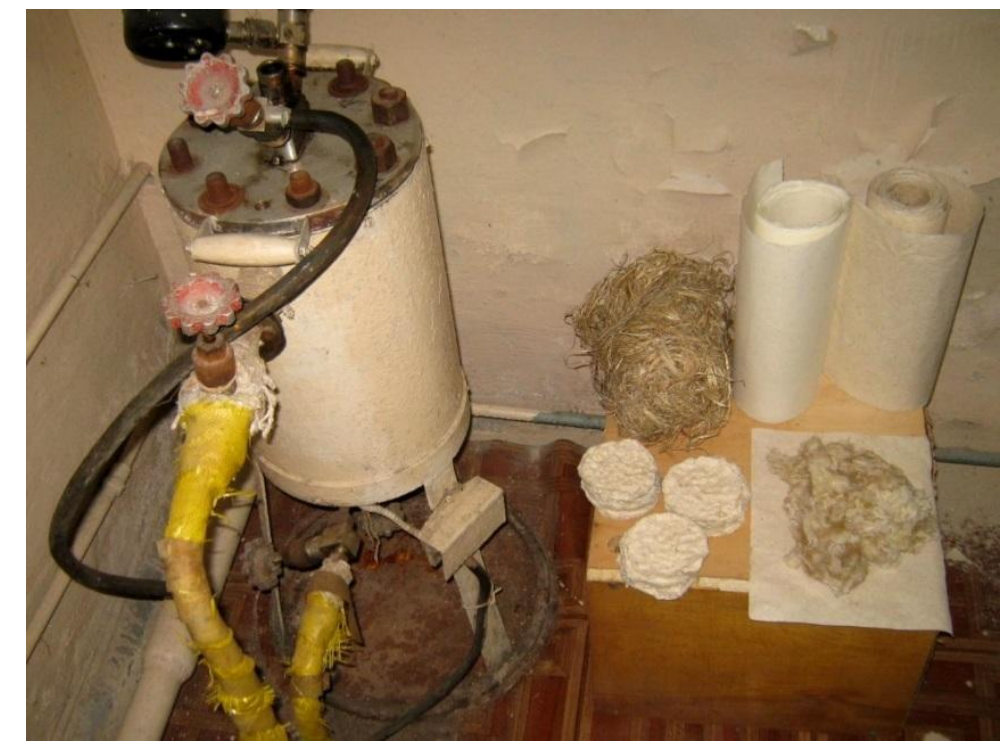

Рис. 1. Лабораторна установка ВК-1 для варіння целюлози

Якісні показники паперу, волокниста композиція якого складається 3 конопляного лубу та хвойної целюлози, і з волокон льону олійного та деревної целюлози подано в таблиці 4. Показники якості, наведені в таблиці 4, свідчать про високу повітропроникність паперу, виготовленого як із додаванням конопляного лубу, так і лляного волокна. 
Таблиця 4. Показники якості паперу із композицій рослинної та деревної целюлози у співвідношенні 1:1

\begin{tabular}{|l|c|c|c|}
\hline \multirow{2}{*}{ Найменування показника } & Метод вимірювання & $\begin{array}{c}\text { Велюлоза, } \\
\text { отримана 3 } \\
\text { лубу } \\
\text { конопель }\end{array}$ & $\begin{array}{c}\text { целюлоза, } \\
\text { отримана 3 } \\
\text { волокна } \\
\text { льону } \\
\text { олійного }\end{array}$ \\
\hline Маса 1 м², г $^{2}$ & $\begin{array}{c}\text { ДСТУ 2297-93 (ГОСТ } \\
13199-94)\end{array}$ & 111 & 97 \\
\hline $\begin{array}{l}\text { Повітропроникність, л/ } \\
\text { (м²) }\end{array}$ & $\begin{array}{c}\text { ДСТУ 2906-94 (ГОСТ } \\
\text { 30114-95) (ISO 5636- } \\
1: 1984)\end{array}$ & 620 & 750 \\
\hline Білість, \% & $\begin{array}{c}\text { ДСТУ 2570-94 (ГОСТ } \\
\text { 30113-94) }\end{array}$ & 85 & 83 \\
\hline $\begin{array}{l}\text { Абсолютний опір } \\
\text { продавлюванню, кПа }\end{array}$ & ДСТУ ISO 2758:2007 & 65 & 60 \\
\hline
\end{tabular}

Отримані дані підтверджують, що можна одержувати целюлозу не тільки 3 волокна льону, а й із луб'яної частини стебла - конопляного лубу. У свою чергу, використання лубу замість конопляних волокон зменшить вартість целюлози, дозволить отримати високоякісну целюлозу, зменшить вартість продукції, виготовленої з неї. Крім того, луб вважається збагаченою сировиною порівняно з соломою та очеретом, крім того, він легко сушиться, упаковується, транспортується, а в повітряно-сухому стані придатний для тривалого використання.

Висновки та перспективи подальших досліджень. Таким чином, результати досліджень підтверджують можливість отримання високоякісної целюлози з ненаркотичних сортів конопель та льону олійного. Порівняльний аналіз якості паперу, отриманого 3 композицій з додаванням волокна та лубу, показує, що целюлоза, отримана з лубу, не поступається целюлозі, виготовленій 3 волокна. $\mathcal{C}$ великі перспективи виробництва високоякісного паперу (для банкнот, карт, документів, цінних паперів) із довговолокнистої целюлози. Цей вид целюлози, а також технологія іії виробництва можуть бути впроваджені як в Україні, так і за кордоном.

Виходячи зі світових тенденцій, слід зазначити, що льонарство й коноплярство належать до інвестиційно привабливих галузей, майбутнє яких залежатиме насамперед від державної політики, інтересу інвесторів та комплексного підходу до їх розвитку. 
Розробка технології переробки соломи льону олійного та ненаркотичних сортів конопель у целюлозу дозволить раціонально використовувати власні ресурси України та створити вітчизняну сировинну базу целюлозовмісних матеріалів для різних галузей промисловості.

\section{Список використаних джерел}

1. Завод по производству целлюлозы из конопли. Техническая конопля в Украине и других странах: веб-сайт. URL: http://tku.org.ua/ru/завод-по-производству-целлюлозы-изконопли (дата звернення: 08.02.2021).

2. Ляліна Н.П. Розвиток наукових основ первинної переробки стебел ненаркотичних конопель для отримання волокон різного функціонального призначення: дис. ... док. техн. наук: 05.18.02. Херсон, 2015. 335 с.

3. ДСТУ 2297-93 (ГОСТ 13199-94). Напівфабрикати волокнисті, папір та картон.

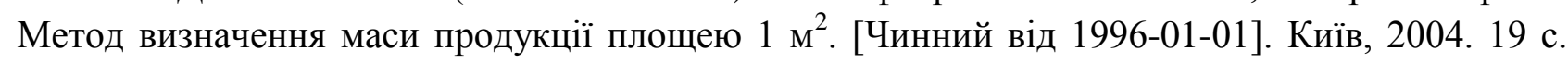
(Національний стандарт України).

4. ДСТУ 2906-94 (ГОСТ 30114-95) (ISO 5636-1:1984). Папір та картон. Визначення повітропроникності (середній діапазон). Загальні вимоги до методів. [Чинний від 1996-0701]. Київ, 2004. 8 с. (Національний стандарт України).

5. Путінцева С.В. Властивості фільтрувального паперу на основі целюлози з волокон льону олійного: автореф.дисерт.канд.техн.наук: 05.18.08. Луцьк, 2015. 183 с.

\section{References}

1. Zavod po proizvodstvu celljulozy iz konopli. Tehnicheskaja konoplja v Ukraine i drugih stranah [Plant for the production of hemp pulp. Industrial hemp in Ukraine and other countries]: veb-sajt [website] URL: http://tku.org.ua/ru/завод-по-производству-целлюлозы-из-конопли (Last accessed: 08.02.2021) [in Russian].

2. Lialina N.P. Rozvytok naukovykh osnov pervynnoi pererobky stebel nenarkotychnykh konopel' dlia otrymannia volokon riznoho funktsional'noho pryznachennia [Development of scientific bases of primary processingof drug-freehemp stalks for receiving fibers of a different functional purpose]. Extended abstract of Doctor's thesis. Kherson, 2015. [in Ukrainian].

3. DSTU 2906-94 (GOST 30114-95) (ISO 5636-1:1984) Napivfabrykaty voloknysti, papir ta karton. Metod vyznachennia masy produktsii ploscheiu $1 \mathrm{~m}^{2}$ (2004) [Semi-finished fibrous, paper and cardboard. The method of determining the mass of products with an area of 1 sq.m.] from January 1, 1996. Kyiv. 19 s. [in Ukrainian].

4. DSTU 2906-94 (GOST 30114-95) (ISO 5636-1:1984) Papir ta karton. Vyznachennia povitropronyknosti (serednij diapazon). Zahal'ni vymohy do metodiv (2004) [Paper and cardboard. Determination of air permeability (middle range). General requirements for methods] from June 1, 1996. Kyiv. 8 s. [in Ukrainian]. 
5. Putintseva S.V. Vlastyvosti fil'truval'noho paperu na osnovi tseliulozy z volokon l'onu olijnoho [Properties filter paper based on cellulose fibers from flax oil]. Extended abstract of candidate's thesis. Lutsk, 2015. [in Ukrainian].

Purpose. To carry out a comparative analysis of paper obtained on the basis of flax fiber and non-narcotic hemp.

Methodology. The research was carried out using modern theoretical and experimental methods: an experimental study of flax and hemp paper properties was performed using standard methods and measuring tools, including the next: the weight of $1 \mathrm{~m}^{2}$ of paper was determined by the instrumental method according to DSTU 2297-93 (GOST 13199-94) «Semi-finished fibrous, paper and cardboard. Method for determining the product mass with an area of $1 \mathrm{~m}^{2} »$; determination of air permeability in accordance with DSTU 2906-94 (GOST 30114-95) (ISO 5636-1: 1984) «Paper and cardboard. Determination of air permeability (middle range). General method requirements»; whiteness determination in accordance with DSTU 2570-94 (GOST 30113-94) «Paper and cardboard. Whiteness determining method»; determination of absolute pushing resistance in accordance with DSTU ISO 2758: 2007 «Paper. Determination of pushing resistance (ISO 2758: 2001, IDT)»; results of experimental studies were treated using the methods of mathematical statistics on the applications «MathCAD-2000», «Maple 6,5», «Microsoft Office Excel 2016» and «Microsoft Office Word 2016».

Results. The quality indicators of classical composition paper (respectively from cotton and wood pulp) and based on vegetable raw materials composition (cellulose from the fiber of flax oil + wood cellulose; cellulose from hemp bast + coniferous cellulose) are analyzed; the possibility of obtaining high-quality cellulose from non-narcotic types of hemp and flax oil is confirmed; a comparative analysis of the obtained types of paper was held; the recommendations on improvement of processing technologies of oil flax straw and non-narcotic grades of hemp into cellulose (that allow rational use own resources) are given.

Scientific novelty. The influence of different types of celluloses obtained from oil flax fibers and non-narcotic hemp on the physical and mechanical properties of the obtained grades of paper is determined. A comparative analysis of quality was performed.

Practical significance. Based on the obtained consumer characteristics of paper of different grades, it is possible to establish their functional purpose and application in different industries. The bast paper consumption characteristics established in the work confirm the feasibility of replacing imported raw materials of cotton and scarce wood raw materials to obtain different types of paper.

Key words: non-narcotic hemp, paper, cellulose, fiber, oil flax.

Стаття рекомендована до друку доктором технічних наук, професором Херсонського НТУ Тіхосовою Г.А. Дата надходження статті в редакиію 04.01.2021 p. 